\title{
Can students be "nudged" to develop their employability? Using behavioural change methods to encourage uptake of industrial placements
}

\author{
Julie Fowlie and Clare Forder*, Brighton Business School, University of Brighton
}

*corresponding author: c.l.forder@brighton.ac.uk

\begin{abstract}
Preparing students for employment involves encouraging ownership of their employability and engagement in opportunities that can help them improve it. Industrial placements play an important role in this but declining numbers of students are undertaking them. Using data collected over a three-year period at a Business School in a UK university, this paper will explore an intervention based on nudge theory designed to increase the uptake of these placements. Drawing upon behavioural science, it will explore nudge theory and its criticisms. It will discuss the concept of employability, including the tensions between the necessity of promoting students' ownership of theirs and the inherent assumptions that they will engage in opportunities to achieve this. Critical assessment of how the nudge intervention worked will be provided, demonstrating how almost half of those 'nudged' responded positively, thereby successfully increasing the uptake of placements. It will identify soft outcomes, notably the breaking down of some typical behavioural barriers to placements and encouraging students to think reflectively. It will offer recommendations for replicable practice in other universities; specifically a model for developing nudges not only in relation to employability but within higher education more broadly. It concludes by proposing a new pedagogic definition of employability.
\end{abstract}

Keywords: employability; nudge theory; higher education; work placement 


\section{Introduction}

It is well-recognised that undergraduate industrial placements (a period of work typically undertaken for approximately 10-12 months during the third year of a degree programme also referred to as 'work placement') provide additional benefit to students and universities in relation to employability (Wilton 2012; Helyer and Lee 2014) and outcomes measured by such instruments as the Graduate Outcomes survey (formerly the Destination of Leavers from Higher Education (DLHE) survey) as well as the annual graduate market report produced by High Fliers (www.highfliers.co.uk). While for many the benefits and positive outcomes of undertaking a year in industry during a degree programme is obvious and even the primary reason for choosing a particular course, for others the advantages a placement can offer are not as enticing. This has resulted in a decline in the uptake of industrial placements over recent years (Lock et al. 2009; Bullock et al. 2009; Jones, Green and Higson 2017).

Reasons behind the decline are varied but typically include a combination of instrumental and behavioural barriers, as we will explore below. This calls into question how students themselves view employability and the benefits of engaging in employabilityenhancing activities. It suggests that undergraduates may not be aware of the importance of taking responsibility for their employability by making the most of the opportunities available to them (Hepworth et al. 2015).

We propose that one way of increasing the uptake of industrial placements and thereby underlining the value of being responsible for one's employability is by designing interventions based on nudge theory (Thaler and Sunstein 2008). Already applied successfully in many areas of higher education, it appears that such an approach can achieve positive outcomes. We will explore the ideas behind the theory and demonstrate how it has been applied locally. 


\section{Nudge theory}

Thaler and Sunstein (2008) in their seminal work on a variant of behavioural change they termed 'nudge' theory, lay out their approach as a means of influencing behaviour to improve people's lives for the better. A key tenet of this is not using force or coercion to generate change but providing choices that do not forbid other options or significantly change economic incentives (6). Those providing such choices are known as 'choice architects' (3) and it is their role to design an intervention that is easy to avoid (6), but that will increase the likelihood of those targeted making a choice that is in line with the intended outcome (Oliver 2013). This is known as a 'nudge'.

There is plenty of debate in the literature around the philosophical underpinnings and ethical considerations involved in this approach (Hausman and Welch 2010; Heilmann 2014). A main concern is that nudges manipulate rather than inform choice (White 2013; Wilkinson 2013). These arguments are usually located in the contexts of public policy and express a range of social, political, and moral objections to the concept of nudging (Furedi 2011; Selinger and Whyte 2011; Goodwin 2012). Critics question whether nudges really offer choice, arguing that they may 'subject us to the control of others because of the mechanisms through which they operate' (Saghai 2013, 487). In a similar vein, others have suggested that nudging represents a mechanism where those with 'requisite scientific and behavioural expertise are seen to be much more capable than ordinary people in determining what constitutes rational, health or prudent behaviour and how best to engineer it' (Pedwell 2017, 74).

However, Hansen and Jespersen (2013), whilst identifying similar arguments, also recognise that not all nudges are equal. They realise the flaws in each side of the debate and posit that evaluating whether a nudge is a form of manipulation may rest on how far it can be 
recognised as transparent $(2013,18)$. Of the four conceptual models of nudges they develop, one which is transparent and results in change as a result of reflective thinking on the part of those being influenced is classed as an 'empowerment' nudge (Hansen and Jespersen 2013, 24). The intervention we discuss later adheres to this model. Whilst opponents of this approach believe that nudges are 'marred by a tendency to disempower' (Jones et al. 2012, 52), we argue that nudging as transparently as possible can prompt choices that benefit those making them. This is supported by the fact that nudge theory is based in part upon the premise that it is more effective to encourage people to do something than it is to get them to stop (Halpern, 2015).

Although transparency and empowerment may counter claims of choice manipulation, another criticism levelled at nudge theory is that its largely universal approach (Thaler and Sunstein 2008,9$)$ leaves no room to address issues of equality. Wells $(2010,116)$ states that 'scant attention is given to the variation in the capability of individuals to make decisions, let alone the material resources individuals may have to exercise agency or a behavioural change when confronted with a nudge'. This is echoed by Roberts $(2018,1047-48)$ who notes that structural barriers and social constraints mean that we are not all equally autonomous and therefore neither are we equally nudge-able. Developing this argument further, she maintains that choice architecture assumes the ability to choose (op cit, 1059). In our context we address this argument by using the nudge itself to better understand and navigate the barriers and constraints students may face which could limit their capacity to respond to it. In a situation where reasons behind students' decision-making is often not immediately clear, implementing a nudge can help bring them to the fore and under discussion. As what is chosen very often depends on how the choice is presented (Johnson et al. 2012) we maintain that nudging can help remove barriers, a view endorsed by the detailed review of nudges in education offered by Damgaard and Nielsen (2018), who argue that nudges often bring about 
the greatest effects for those affected most by the behavioural barrier targeted by the intervention.

Despite criticism, nudge theory has also received positive reception in many areas, including the workplace environment (Hall-Ellis 2015), informed consent in healthcare (Brooks 2013; Cohen 2013), lifestyle (Marlo 2014), and environmental policy (Ölander and Thøgersen 2014). There also exists a growing body of literature on nudges in higher education. For example, Fritz (2017) explores how the use of learning analytics might nudge students' responsibility for learning; Smith et al. (2018) discuss how emailed grade nudges explaining how an assignment will affect students' final marks improved homework performance; Pugatch and Wilson (2018) identify how nudging students to engage in peer tutoring services saw a significant increase in take up; Davies (2019) describes how nudges are used to help support students' mental health. Each of these examples corresponds well to the transparent, empowerment-style nudge as described above.

Employability, however, is an area of higher education that remains relatively unexplored in terms of implementing nudges. Interestingly, Yorke and Knight's $(2006,12)$ assertion appears to precede the underlying themes of Thaler and Sunstein's (2008) work:

Students whose self-theories are apparently fixed may, given appropriate 'messages', be encouraged to revise them in the direction of malleability. Revision is more likely when students are presented with a consistent affirmation that the sort of intelligence that is valued in the workplace differs from the supposedly-fixed intelligence which is widely believed to determine success or failure.

Their suggestion ties in closely with the ethos of nudge interventions and thus forms the basis of intervention discussed below. Additionally, Deutschman's (2007) framework for change aligns with these beliefs, examining how facts, fear, and force as agents of change are 
misconceptions. He describes three keys to change: relate, repeat, and reframe, each of which focus on forming a new relationship with something that inspires or sustains hope $(2007,14-$ 15). The concept of "reframe" is particularly useful here as it correlates with learning new ways of thinking, which is essentially what we aim the nudge to provoke.

\section{Employability}

'Employability' takes on many different definitions. It is recognised throughout the literature as: the propensity of students to obtain a job (Harvey 2001); a form of work-specific adaptability (Fugate, Kinicki and Ashforth 2004); the set of skills, knowledge, understanding and attributes that make a person more likely to choose occupations in which they can be satisfied and successful (Dacre Pool and Sewell 2007). The complexity of the concept is outlined by Andrews and Higson $(2008,413)$ who note that it is both difficult to articulate and define. Later Pegg et al. $(2012,20)$ find that employability raises a "definition dilemma".

Contributing to this dilemma is the difference in perspective that governs how employability is viewed and the tensions it thereby creates. Employers largely see it as 'work readiness', i.e. the ability of graduates to hit the ground running by being in possession of the skills, knowledge, attitudes, and commercial understanding that are immediately valuable (Archer and Davison 2008; Mason et al. 2009). For students and graduates however, it is most often seen as the "set of achievements...that makes [them] more likely to gain employment and be successful in their chosen occupations" (Knight and Yorke 2003, 5). The Higher Education Academy's (2015) framework for employability advises developing a shared understanding and view of employability to facilitate staff, employer, and student engagement. Although Clarke $(2017,9)$ goes some way by suggesting its reconceptualisation as "the human capital, social capital, and individual behaviours and attributes that underpin an individual's perceived employability, in a labour market context, and that, in combination, 
influence employment outcomes", a definition of employability combining both outlooks has yet to be achieved.

As such, higher education institutions (HEIs) essentially straddle two perspectives. On one hand they must respond to employers' requirements in producing graduates equipped with the skills necessary to perform well in the workplace (Pollard et al. 2015), but at the same time, they must also instil in students the ability to gain those jobs in the first place (Helyer and Lee 2014). In this context, we believe that undertaking an industrial placement is a principal way of not only developing critical workplace skills but also increasing the likelihood of securing a job (or place on a graduate scheme) after graduation. The literature on industrial placements upholds this view: Andrews and Higson (2008) and Attwood (2010) determine that work experience is essential for graduate employability; Mason et al. (2009) find that placement students are more likely to have found employment six months after graduation than non-placement students; Brookes (2012) notes that placement students are more likely to secure places on competitive graduate training schemes; High Fliers Research (2018) highlights that companies are more likely to hire candidates who have previously undertaken work experience with them . Recent data from our own department substantiates this, with $34 \%$ of $2018-19$ placement students offered a role after graduation. A further $46 \%$ would be considered for a role if there were one available after they had graduated.

However, despite the number of paid work experience opportunities set to increase in 2019 (High Fliers 2019), the number of students seeking them, particularly in the form of industrial placements, is in decline. Our study sought to moderate this locally by employing methods developed from behavioural change approaches (Thaler and Sunstein, 2008). Before drawing specifically on how we have implemented this in our own institution, it is useful to consider what takes place in the context of developing students' employability and before decisions to undertake industrial placements are made. 


\section{Enhancing employability: a multitude of options}

\section{Careers and employability services}

Across most disciplines, today's students are exposed to a wide variety of career-enhancing opportunities during their time at university, of which four strands can be identified. First, there is provision of careers and employability services usually found on-campus. As there is already a body of literature exploring higher education careers services (Watts 1997; Harris 2001; Rowley and Purcell 2001) there is no need to revisit it here. However, in broad terms these services allow students to access information, advice, and guidance on career pathways. They are catalysts for employer-university engagement and play a significant role in linking students with employers (Lowden et al. 2011). In some instances they also offer support beyond graduation.

\section{Employability in the taught curriculum}

Second, opportunities for students to enhance their employability are often embedded into the taught curriculum. The aim of this is typically to encompass academic and 'practical' intelligence (Yorke and Knight 2006) and it can occur in a variety of ways: through individual or a set of core modules, across a whole curriculum, or as a bolt-on (Cranmer 2006). It can also be compulsory or optional. There are certainly some tensions at the institutional level regarding implementation, with many arguing that this may dilute discipline or subject curricula (Speight et al. 2013) and others casting doubt on the effectiveness of classroom-based employability teaching and learning (Mason et al. 2003; Cranmer 2006). However, with some debate around the skills gap in the graduate labour market (Jackson 2013; Moore and Morton 2017; Osmani et al. 2019) it has become increasingly important to adjust curricula and pedagogy to enhance graduate skill outcomes (Jackson 2014). 


\section{Extra-curricular activities}

Third, students can boost their employability through participating in an extensive array of extra-curricular activities (ECAs). These are usually offered by HEIs but can also be sought independently. Some of the most well-recognised options involve undertaking some form of volunteering (Holdsworth 2010; Holdsworth and Brewis 2014); playing sport (CBI/NUS 2011; Thompson et al. 2013); and part-time work (Muldoon 2009; Gbadamosi et al. 2015). Also included but less well-documented in the literature is students' access to numerous clubs, societies, networking events, guest lectures, as well as the development of their own interests (Watson 2011). Roulin and Bangerter (2013) examine further the role of ECAs and assert that students are attuned to their importance as a means of not only developing but also showcasing their employability, particularly with regard to competitive jobs markets. Importantly, Clark et al. (2015), through discussing the value of ECAs with alumni, highlight the long-lasting affect these can have on one's employability.

\section{Placements, internships, and work-based learning}

Fourth, a long tradition of industrial placements, internships, and work-based learning provides students with another means of enhancing their employability (Andrews and Higson 2008; Hall, Higson and Bullivant 2009; Lowden et al. 2011). These may take many forms, such as short-term, year-long, mandatory or optional, paid or unpaid. Securing a placement typically necessitates engagement in the majority of the opportunities discussed above, particularly during the year prior to the placement. Aside from developing the skills and competencies that come under the umbrella of employability, a placement can also provide a head start for graduates in the early stages of their career (Wilton 2012) as well as a higher starting salary (Brooks and Youngson 2016). It builds on the foundations gained and experienced in traditional classroom settings and encourages students to apply this 
knowledge in a practical setting (Jackson 2015). A vast range of opportunities to do so exists across large, multinational firms, through to smaller, local companies.

These strands all serve to help students understand, articulate, and develop their employability. But do students appreciate that this array of activities underpins the central goals of improving their work readiness and ability to seek and gain employment?

\section{Taking ownership of employability}

Lack of student engagement (for various reasons) and difficulties with implementation can restrict the value of the above-mentioned opportunities. For each of the strands identified there is an inherent expectation that students will actively choose to benefit from them. However, research has demonstrated otherwise. For example, Archer and Davison (2008) find that students are not proactive in their use of careers and employability services, with Greenbank (2011) noting that they may choose not to make use of them at all. Tymon (2013, 853), whilst considering if HEIs are "able, willing or designed to develop employability", finds that even when such activities are embedded into the curriculum, many first- and second year students do not seem to engage with them. Similarly, some students may even try to avoid experiencing them (Atlay and Harris 2000).

Stevenson and Clegg (2011) also note the critical importance of extra-curricular activities as means of enhancing employability but find that students mainly participate in them not for reasons of employability and building their future selves but to maximise the opportunities of the present. Additionally, Pegg et al. (2012) observe that widening participation, part-time, and mature students are less likely to take part in extra-curricular activities. 
Finally, many barriers to undertaking placements exist. These obstacles, among others, often include: wanting to graduate quickly without adding another year onto their studies (Morgan 2006); belief that they already have enough work experience (Bullock et al. 2009); unrealistic expectations, lack of experience, and poor academic performance (Balta et al. 2012). In addition to these largely instrumental factors, in practice we discover on a regular basis that there are also numerous behavioural barriers at play in this decisionmaking. These may include but are not limited to lack of confidence (Bullock et al. 2009), disinterest or doubt (Aggett and Busby 2011), and not appreciating the longer-term benefits (Brooks and Youngson 2016). Consequently, a number of students on sandwich degrees often opt out of their placement year and move from a four- to three-year pathway (Little and Harvey 2006).

These findings hint at the fact that students may not being taking responsibility for their own employability and do not share the view of careers and academic staff that they need to engage fully with employability activities (Hepworth et al. 2015, 48). Low engagement and lack of responsibility can be further affected by way in which employability is typically addressed. Because employability as a learning outcome can often be the result of a combination of approaches (as outlined above), students may not see the connection between each one (Rae 2007, 608). As a result, opportunities for students to develop their employability cannot exist in isolation. Promoting students' ownership of their employability is necessary in order to help them understand how and why these skills are being developed, and why this is important (Baker and Henson 2010).

\section{Business School context}

At our Business School, and no doubt in other departments and institutions, this reluctance to engage with the placements strand of employability (and subsequently elements of the other 
strands) is often further displayed in students' enrolment patterns. Looking specifically at Business courses, students can choose to follow a three-year route without placement or a four-year route including placement. Placements are sourced and promoted by an in-School Employability Hub, which also provides support and guidance on CV and application writing, as well as interview preparation. This paper focuses on the Business (and associated pathways) students who opt for the three-year route. On average these students account for $30 \%$ of the total Business cohort each year.

Business students who study here on the three-year pathway fall into two different categories. There are those who, despite being provided with information and guidance regarding the value of a year in industry (by either staff or peers), adhere to their decision not to do a placement. There are then those who, either by the end of their first year or once they enter the second year, have realised the value of a placement year. These students, providing their first-year mark meets or exceeds an internally set benchmark of $60 \%$, typically selfselect (i.e. they are not nudged) a transfer onto a four-year route to include a placement. However, the rate of self-selection has declined over the last four academic years, dropping from 31 students in 2014-15 to only three in 2017-18.

Within the cohort of students who do not change course, there are also those whose first-year results exceed the $60 \%$ benchmark, demonstrating they are academically capable of undertaking a placement but still do not choose to transfer to the four-year pathway. These students often appear resolute in their decision not to undertake a year in industry. It is this group who most often display the behavioural barriers to participating in placements as discussed above. The declining number of students self-selecting a transfer to the four-year route suggests that behavioural barriers are becoming more embedded in students' decisionmaking, which in turn potentially reflects a lack of ownership of their employability. Consequently, our research has centred on an intervention rooted in nudge theory designed to 
encourage academically capable students who do not self-select as described to change onto the four-year route to include a placement.

\section{Method}

This research project was undertaken in two parts. First, based on the central principles of nudge theory (Thaler and Sunstein 2008) we designed a simple, straightforward intervention to nudge the behaviour of a group of students identified as academically capable of undertaking an industrial placement. Following ethics approval, this involved sending a letter (by post and email) inviting them to change from a three-year degree without placement to a four-year route including a placement. The letter explained that they had achieved the results necessary to do so and outlined some of the benefits to undertaking a placement. The wording of the letter was chosen carefully to remain in line with the practice of nudge theory; that is, to ensure those being influenced understood it was optional and that they were not being forced to change anything:

...In light of your results we would like to offer you the option of changing from the three-year non-placement route to the four-year Business Management option with one year's work placement.

In addition, the nudge was transparent, fully explaining the benefits of transferring to the four-year course. Finally, it was easy to ignore if the student so wished. They did not have to do anything if they did not want to change course and only needed to take action if this was something they decided to pursue.

Second, following a pilot, we conducted a survey with students who had received the intervention $(n=147)$. Prior to completion, participants were made aware that their responses would remain anonymous. Using Qualtrics, students were asked to complete nine questions 
based on the intervention, whether or not they acted it upon it, and how it made them feel. Space for any additional comments was also provided.

\section{Results}

In the academic year 2016-17, 34 students on non-placement pathways were invited to change to a Business Management (and associated pathways) degree including a placement. In 2017-18, a further 67 students were invited to do the same, followed by 46 students in 2018-19. Table one below shows these figures as part of the wider school context:

[Table one: number of students nudged and responding to nudge]

Of those who responded to the nudge, not all succeeded in securing a placement. However, the data for $2016-17$ show that $43 \%$ of responding students undertook a placement, contributing to $4 \%$ of all placed students that year. In $2017-18,30 \%$ of responding students also undertook a placement, contributing to $11 \%$ of all placed students; with $39 \%$ of responding students undertaking a placement in $2018-19$, contributing to $12 \%$ of all placed students.

The response rate for the survey on the nudge was $36 \%$. This is possibly due to it being issued at a busy time for placement students and at the beginning of the examinations period for those who had yet to start theirs. However, looking at the qualitative data gathered, we can identify some emerging trends. To start, $57 \%$ of respondents indicated that at the start of their degree programme they had not intended to do a placement. While some respondents claimed that they felt they had left it too late to change course or that they simply "did not see any additional benefits to what [they] wanted from their degree", $78 \%$ stated that they decided to change their course after receiving the nudge (letter). 
Qualitative data were coded according to the principles of Grounded Theory (Glaser and Strauss 1967), using an inductive approach rather than fitting data into any pre-defined themes. Those who responded positively to the nudge noted that it made them feel very positive. Answers to the question "how did the invitation to change to management make you feel" included:

Now motivated to look for the best possible placement

Motivated to gain a placement and that my degree has more meaning

Good, like I had achieved more than I thought I was able to

Really proud that I had worked hard enough to merit the change

Capable of coming out with a strong degree

Happy and welcomed

However, some respondents gave more negative answers:

As if the university was trying to get me to change because it would suit them better

Like it was questioning my choice

It did not change anything as I knew from the beginning I did not want to do a placement year

The question "in what way(s) did being invited to change course help you" also prompted positive responses which can be grouped according to distinct themes:

\section{Feeling motivated}

Motivated me to work harder and excited me to start work in the real business world 
Made me more motivated to do well

Motivated me to try harder in the second year

It made me feel more motivated in my studies

\section{Boosting confidence}

Made me feel confident I can get a placement

Gave me confidence in my abilities

It gave me the confidence to apply for the placements I thought were more difficult

\section{Helping with decision-making}

Helped with the decision to do a placement

It helped me decide to try and get a placement year

It made me think of doing a placement year

\section{Preparing for the future}

Allowed me to start thinking about what career I wanted

It allowed me to start focusing directly on a career path and realise my potential

Helped me think about how it would look for future employers

Made me realise that it...would benefit me coming out of university

It opened my eyes to what options I have to customise my time at university

Taught me to prepare more for upcoming situations

Felt more optimistic about the prospect of finding employment after university 


\section{Discussion}

\section{Behavioural change}

These responses are interesting in that they reveal the behavioural barriers the students may have been experiencing. Comments referencing confidence, excitement, encouragement, and support as a result of receiving the nudge perhaps indicate that these elements had been lacking beforehand and thus may have contributed to the decision not to undertake a placement as outlined by Bullock et al. (2009), Aggett and Busby (2011), and Balta et al. (2012). Therefore, we can argue that the nudge contributed to breaking down some of the behavioural barriers often experienced by students when thinking about placements, echoing Pugatch and Wilson's $(2018,160)$ findings that students change their behaviour in response to specific messages. As the nudge also positively affected some students' outcomes (i.e. they secured a placement) we can also tentatively suggest that this intervention has been more successful in changing behaviour than the other employability-related activities to which the responding students had already been exposed.

However, it is prudent to also examine the less positive reactions to the nudge. Three students outlined how it did not make them change their minds, each expressing different types of reasoning: belief that the nudge was related to the university's best interests; the impression of being questioned; and resolute decision-making that could not be changed. For the purpose of this study, the first response is of most interest. The nudge implemented was designed to highlight the benefits to the student of undertaking a placement year; it did not mention any value or gain to the university itself. That the student inferred this lends some weight to the argument that nudges can be seen as manipulative. It also echoes the distinction made by Brown et al. (2004) in their observations on the strategies students and graduates use to compete for jobs. They identify 'Players' and 'Purists' (op cit, 115) as two different types 
of student: those who can market themselves to fit what employers are looking for, and those who believe in a more meritocratic approach respectively. Without additional context, it is impossible to determine if this one student in particular was aware of such distinctions but their comment, along with those made by the other two respondents, reminds us that in applying nudges we should not assume intended recipients will all react in the same way.

The comment made by the student who felt their choice was being questioned could also be an indication of feeling manipulated. However, following Sunstein (2015), we can draw upon the concept of defaults to underline how the nudge in this instance was not manipulative but acted as an opportunity to provide choice. As outlined by Sunstein $(2015,17)$, life cannot be navigated without default rules. In the student's context, the default path was not to undertake a placement year. That the nudge did not suppress this choice but simply offered sufficient information to allow for an element of reflective thinking also highlights the absence of manipulation on the part of the nudgers. As already discussed, the nudge implemented here was a presentation of options that could easily be followed through or discarded without obligation. It allowed students to review their original choice (i.e. the three year, no placement route) and to continue with it if they desired. With choice being preserved in such a manner, and in line with the transparency required by empowerment nudges, concerns around manipulation can be dispelled.

\section{Validity of the nudge}

The responses also demonstrate a change in students' thinking. The comments referring to how the nudge made respondents realise, think or decide indicate reflective thinking, or the deliberate and conscious processing of information as associated with self-awareness, agency, autonomy, and volition (Hansen and Jespersen 2013, 13). That this is evidenced in reaction to the nudge suggests that the nudge itself cannot be seen as an act of manipulation (Sunstein 
2015). With evidence that placements are beneficial (Wilton 2012; Helyer and Lee 2014), and students still opting out of undertaking them we can suggest that this approach has contributed to increased agency in the placements process. This adds further validity for executing the nudge in the first place (Nys and Engelen 2016).

The development of reflective thinking also contributes to an overall improvement in students' employability. Remembering Harvey's (2003) assertion that employability is not just about getting a job, but being able to develop critical and reflective abilities, we propose that the act of nudging targeted students has helped enhance their employability regardless of whether or not they secured a placement. As well as empowering students, we have also contributed to a reframing (Deutschman 2007) of the way they think.

\section{Determining success}

Following the suggestion of Kosters and Van der Heijden $(2015,285)$ we evaluate the success of this nudge by focusing on both hard and soft outcomes. The hard outcome is the increase in the number of placements undertaken as a result of selected students receiving the nudge. Whilst accounting for small percentage of the total number of placed students we view this as a success for two reasons: one, the nudge did what we hoped it would do and increased the number of placements; two, the percentage of placements it helped secure saw a year on year increase from $4 \%$ to $12 \%$.

However, perhaps more useful than statistics are the soft outcomes generated by the nudge. In addition to breaking down some behavioural barriers and prompting reflective thinking as discussed above, we can also identify a change in overall attitude towards students' own self-theories as suggested by Yorke and Knight (2006). Here we note that the receivers of the nudge began thinking of themselves as more capable and more open to opportunities, thereby becoming more malleable (Yorke and Knight 2006, 12). There is also a 
change in terms of thinking ahead to the future. Whereas prior to the intervention most $(57 \%)$ students were interested only in the three-year route, after the nudge their comments demonstrated a revised view. They felt more motivated, capable of achieving a good degree, began looking ahead to what career they might follow after university, and started to think what future employers might want. Obviously it is impossible to determine with absolute certainty that they would not have engaged in such thought processes without receiving the nudge. However, by following Kosters and Van der Heijden's $(2015,286)$ logic that nudges can also be evaluated against an alternative strategy (in this case: no direct action taken to encourage academically capable students to undertake a placement) we can suggest that the nudge has influenced this change in thinking.

A final soft outcome can also be found in the increase in the number of students who engaged with the Business School's placements team. In total, 59\% of 'nudgees' in the 201617 group, $60 \%$ of 'nudgees' in the $2017-18$ group, and 78\% of 2018-19 'nudgees' made contact with the placements team. Earlier we outlined engagement with careers or employability services as one of the employability-enhancing opportunities students sometimes do not make use of (Archer and Davison 2008; Greenbank 2011). After implementing the nudge we can assert that while it may not have resulted in all influenced students securing a placement, there was a significant increase in the number of them taking steps to be responsible for their employability.

\section{Conclusion and recommendations}

We advocate that nudge theory in the specific context of undergraduate employability can be used to successfully increase the uptake of industrial placements. In this sense it has been an important tool for encouraging students to take responsibility for their employability. We recognise the limitations of our small-scale study and realise that the results cannot be 
generalised. However, the combination of hard and soft outcomes indicates that there is some value to this approach. We recommend, therefore, that a transparent, 'empowerment' nudge (Hansen and Jespersen 2013) be considered in other institutions where academically capable students have opted out of the placement option at enrolment stage.

We also suggest that a broader application of nudge theory may well suit many other circumstances where not only change but also the empowerment of students is necessary. We know from Deutschman's (2007) ideas that a wide broadcast of facts is not always successful in effecting change, therefore targeted and structured nudges appear a practical means of achieving it. We conclude by offering a model for adapting nudge theory that may suit not only the employability agenda but also other contexts in higher education. It includes initial steps for defining reasons for change and establishing why it has not already occurred; moves through to the nudge itself, encompassing behavioural change (i.e. the response to the nudge), and the need for it to be relatable, transparent and empowering; then finally outlines the expected outcomes of the intervention, such as evidence of reflective thinking, positive change in self-theory, and signs of students starting to take responsibility (whether for employability, learning or any other aspect):

[Figure one: influencing behavioural change in higher education students]

Finally, we put forward a revised definition of a pedagogic approach to employability, arguing that it goes beyond focusing purely on graduate attributes and experience. Preparing 'work ready' graduates includes developing their capacity for self-reflection and encouraging a sense of agency in shaping their future professional selves. Agency is a natural successor to empowerment and thus the added emphasis in our definition ties in well with a behavioural change approach to helping students take responsibility for their employability. 


\section{References}

Aggett M. and G. Busby. 2011. "Opting out of internship: Perceptions of hospitality, tourism and events management undergraduates at a British University." Journal of Hospitality, Leisure, Sport and Tourism Education 10 (1): 106-113. doi:10.3794/johlste.101.310

Andrews, J. and Helen Higson. 2008. "Graduate Employability, 'Soft Skills' Versus 'Hard' Business Knowledge: A European Study." Higher Education in Europe 33 (4): 411-422. doi:10.1080/03797720802522627

Archer, W. and Jess Davison. 2008. Graduate Employability: What do employers think and want? London: Council for Industry and Higher Education.

Atlay, M. and Richard Harris. 2000. “An Institutional Approach to Developing Students' 'Transferable' Skills.” Innovations in Education and Training International 37 (1): 76-84.

Attwood, R. 2010. "We can work it out." Times Higher Education, $2^{\text {nd }}$ September. Accessed $1^{\text {st }}$ November 2019. https://www.timeshighereducation.com/features/we-can-work-itout $/ 413277$.article?sectioncode $=26 \&$ storycode $=413277 \& \mathrm{c}=2$

Baker, G. and Debra Henson. 2010. "Promoting employability skills development in a research-intensive university." Education + Training 52 (1): 62-75.

doi: $\underline{10.1108 / 00400911011017681}$

Balta, M.E., Jane-Lisa Coughlan and Peter Hobson. 2012. "Motivation and Barriers In Undergraduate Students' Decisions to Enrol in Placement Courses in the UK." Journal of International Education Research 8 (4): 399-414. 
Brooks, R. 2012. "Evaluating the impact of placements on employability". In: Employability, Enterprise and Citizenship in Higher Education Conference 2012, 27 $7^{\text {th }}$ March 2012, Manchester Metropolitan University (unpublished).

Brooks, R. and Paul L. Youngson. 2016. "Undergraduate work placements: an analysis of the effects on career progression." Studies in Higher Education 41 (9): 1563-1578. doi: $\underline{10.1080 / 03075079.2014 .988702}$

Brooks, T. 2013. "Should we nudge informed consent?" The American Journal of Bioethics 13 (6): 22-23. doi: $\underline{10.1080 / 15265161.2013 .781710}$

Bullock, K., Virginia Gould, Momna Hejmadi, and Gary Lock. 2009. "Work placement experience: should I stay or should I go?” Higher Education Research \& Development 28 (5): 481-494. doi:10.1080/07294360903146833

Clark, G., Rebecca Marsden, J Duncan Whyatt, Leanne Thompson, and Marion Walker. 2015. “'It's everything else you do...': Alumni views on extracurricular activities and employability." Active Learning in Higher Education 16 (2): 133-147.

doi: $\underline{10.1177 / 1469787415574050}$

Clarke, M. 2017. "Rethinking graduate employability: the role of capital, individual attributes and context." Studies in Higher Education 43:1923-1937. doi:10.1080/03075079.2017.1294152

Cohen, S. 2013. "Nudging and Informed Consent." The American Journal of Bioethics 13 (6): 3-11. doi:10.1080/15265161.2013.781704 
Confederation of British Industry/National Union of Students. 2011. Working towards your future: Making the most of your time in higher education. London: CBI.

Cranmer, S. 2006. "Enhancing graduate employability: best intentions and mixed outcomes." Studies in Higher Education 31 (2):169-184. doi:10.1080/03075070600572041

Dacre Pool, L. and Peter Sewell. 2007. "The key to employability: developing a practical model of graduate employability." Education + Training 49 (4): 277-289. doi:10.1108/00400910710754435

Damgaard, M.T. and Helena S. Nielsen. 2018. "Nudging in education". Economics of Education Review, 64: 313-342. doi: 10.1016/j.econedurev.2018.03.008

Davies, S. 2019. "What has data got to do with student mental health?" [blog post]. Accessed $22^{\text {nd }}$ February 2019. https://wonkhe.com/blogs/what-has-data-got-to-do-with-student-mentalhealth/

Deutschman, A. 2007. Change or Die. New York: HarperCollins.

Fritz, J. 2017. "Using Analytics to Nudge Student Responsibility for Learning.” New Directions for Higher Education 179: 65-75. doi:10.1002/he.20244

Fugate, M., Angelo J. Kinicki, and Blake E. Ashforth. 2004. "Employability: A psycho-social construct, its dimensions, and applications." Journal of Vocational Behavior 65: 14-38. doi: $\underline{10.1016 / j . j v b .2003 .10 .005}$ 
Furedi, F. 2011. "Defending moral autonomy against and army of nudgers." [blog post]. Accessed $20^{\text {th }}$ January 2019. http://www.spikedonline.com/newsite/article/10102\#.W2r1gcL_qUk

Gbadamosi, G., Carl Evans, Mark Richardson, and Mark Ridolfo. 2015. “Employability and students' part-time work in the UK: does self-efficacy and career aspiration matter?" British Educational Research Journal 41 (6):1086-1107. doi:10.1002/berj.3174

Glaser, B. and Anselm Strauss. 1967. The discovery of Grounded Theory: strategies for qualitative research. Chicago: Aldine.

Goodwin, T. 2012. "Why We Should Reject 'Nudge"”. Politics, 32 (2): 85-92. doi: $\underline{10.1111 / \mathrm{j} .1467-9256.2012 .01430 . \mathrm{x}}$

Greenbank, P. 2011. "'I'd rather talk to someone I know than somebody who knows' - the role of networks in undergraduate career decision-making." Research in Post-Compulsory Education 16 (1): 31-45. doi:10.1080/13596748.2011.549726

Hall, M., Helen Higson and Nicola Bullivant. 2009. The role of the undergraduate work placement in developing employment competences: Results from a 5 year study of employers. Birmingham, UK: Aston Business School.

Hall-Ellis, S.D. 2015. "Nudges and decision making: a winning combination.” The Bottom Line: Managing library finances 28 (4): 133-136. doi:10.1108/BL-07-2015-0015

Halpern, D. 2015. Inside the Nudge Unit: How Small Changes Can Make a Big Difference. London: WH Allen. 
Hansen, P.G. and Andreas M. Jespersen. 2013. "Nudge and the Manipulation of Choice: A Framework for the Responsible Use of the Nudge Approach to Behaviour Change in Public Policy.” European Journal of Risk Regulation 4 (1): 3-28.

Harris, M. 2001. Developing Modern Higher Education Careers Services. London: Department for Education and Employment.

Harvey, L. 2001. “Defining and Measuring Employability.” Quality in Higher Education 7 (2): 97-109. doi: $\underline{10.1080 / 13538320120059990}$

Harvey, L. 2003. “Transitions from Higher Education to Work: A briefing paper prepared by Lee Harvey (Centre for Research and Evaluation, Sheffield Hallam University, with advice from ESECT and LTSN Generic Centre colleagues”. [online report]. Retrieved from: $\underline{\text { http://bit.ly/oeCgqW }}$

Hausman, D.M. and Brynn Welch. 2010. “Debate: To Nudge or Not to Nudge.” The Journal of Political Philosophy 18 (1): 123-136. doi:10.1111/j.1467-9760.2009.00351.x

Helyer, R. and Dionne Lee. 2014. "The Role of Work Experience in the Future Employability of Higher Education Graduates.” Higher Education Quarterly 68 (3): 348-372.

doi:10.1111/hequ.12055

Heilmann, C. 2014. "Success conditions for nudges: a methodological critique of libertarian paternalism." European Journal for Philosophy of Science 4 (1): 75-94. doi:10.1007/s13194$\underline{013-0076-Z}$

Hepworth, S., Chris Beaumont, Damien Halligan and Mark Allanson. 2015. Embedding Employability into the Curriculum: An Evaluation of Practice in 3 Departments at Edge Hill University. HEA Strategic Enhancement Programme: Employability. York, UK: Higher Education Academy. 
High Fliers Research. 2018. The Graduate Market in 2018: Annual review of graduate vacancies and starting salaries at the UK's leading employers. London: High Fliers Research Limited.

High Fliers Research. 2019. The Graduate Market in 2019: Annual review of graduate vacancies and starting salaries at the UK's leading employers. London: High Fliers Research Limited.

Higher Education Academy. 2015. The Framework for Embedding Employability in Higher Education. York: The Higher Education Academy.

Holdsworth, C. 2010. "Why Volunteer? Understanding Motivations For Student Volunteering.” British Journal of Educational Studies 58 (4): 421-437.

doi: $\underline{10.1080 / 00071005.2010 .527666}$

Holdsworth C. and Georgina Brewis. 2014. "Volunteering, choice and control: a case study of higher education student volunteering.” Journal of Youth Studies 17 (2): 204-219. doi: $\underline{10.1080 / 13676261.2013 .815702}$

Jackson, D. 2013. “Business graduate employability - where are we going wrong?” Higher Education Research \& Development 32 (5): 776-790. doi:10.1080/07294360.2012.709832

Jackson, D. 2014. “Testing a model of undergraduate competence in employability skills and its implications for stakeholders." Journal of Education and Work 27 (2): 220-242. doi: $\underline{10.1080 / 13639080.2012 .718750}$

Jackson, D. 2015. “Employability skill development in work-integrated learning: barriers and best practice." Studies in Higher Education 40 (2): 350-367.

doi: $\underline{10.1080 / 03075079.2013 .842221}$ 
Johnson, E.J., Suzanne B. Shu, Benedict G.C. Dellaert, Craig Fox, Daniel G. Goldstein, Gerald Häubl, Richard P. Larrick et al. 2012. "Beyond nudges: Tools of a choice architecture.” Mark Lett, 23: 487-504.

Jones, C.M., J.P. Green and Helen Higson. 2017. "Do work placements improve final year academic performance or do high-calibre students choose to do work placements?" Studies in Higher Education 42 (6): 976-992. doi:10.1080/03075079.2015.1073249

Jones, R., Jessica Pykett and Mark Whitehead. 2012. Changing Behaviours: On the Rise of the Psychological State. Cheltenham: Edward Elgar.

Knight, P. and Mantz Yorke. 2003. Assessment, Learning and Employability. London: McGraw-Hill Education.

Kosters, M. and Jeroen Van der Heijden. 2015. "From mechanism to virtue: Evaluating Nudge theory.” Evaluation 21 (3): 276-291. doi:10.1177/1356389015590218

Little, B. and Lee Harvey. 2006. Learning through Work Placements and Beyond. Manchester: HECSU.

Lock, G., Kate Bullock, Virginia Gould, and Momna Hejmadi. 2009. "Exploring the industrial placement experience for mechanical engineering undergraduates." Engineering Education 4 (1): 42-51. doi:10.11120/ened.2009.04010042

Lowden, K., Stuart Hall, Dely Elliot and Jon Lewin. 2011. Employers' perceptions of the employability skills of new graduates. Glasgow: SCRE.

Marlow, M.L. 2014. Weight Loss Nudges: Market Test or Government Guess. Mercatus Working Paper. Virginia, USA: Mercatus Center. 
Mason, G., Gareth Williams, Sue Cranmer and David Guile. 2003. How much does higher education enhance the employability of graduates? Bristol, UK: Higher Education Funding Council for England.

Mason, G., Gareth Williams and Sue Cranmer. 2009. "Employability skills initiatives in higher education: what effects do they have on graduate labour market outcomes?" Education Economics 17 (1): 1-30. doi:10.1080/09645290802028315

Moore, T. and Janne Morton. 2017. "The myth of job readiness? Written communication, employability, and the 'skills gap' in higher education." Studies in Higher Education 42 (3): 591-609. doi: 10.1080/03075079.2015.1067602

Morgan, H. 2006. "Why students avoid sandwich placements." Paper presented at the Education in a Changing Environment conference, Salford, 12-13 ${ }^{\text {th }}$ January 2006.

Muldoon, R. 2009. "Recognizing the enhancement of graduate attributes and employability through part-time work while at university." Active Learning in Higher Education 10 (3): 237-252. doi: $10.1177 / 1469787409343189$

Nys, T.R.V. and Bart Engelen. 2016. "Judging Nudging: Answering the Manipulation Objection.” Political Studies 65 (1): 199-214. doi:10.1177/0032321716629487

Ölander, F. and John Thøgersen. 2014. "Informing Versus Nudging in Environmental Policy." Journal of Consumer Policy 37 (3): 341-356.

Oliver, A. 2013. "From Nudging to Budging: Using Behavioural Economics to Inform Public Sector Policy." Journal of Social Policy 42 (4): 685-700. doi:10.1017/S0047279413000299 
Osmani, M., Vishanth Weerakkody, Nitham Hindi, and Tillal Eldabi. 2019. "Graduates employability skills: A review of literature against market demand.” Journal of Education for Business, 94 (7): 423-432. doi: 10.1080/08832323.2018.1545629.

Pedwell, C. 2017. "Habits and the Politics of Social Change: A Comparison of Nudge Theory and Pragmatist Philosophy." Body \& Society, 23(4): 59-94.

Pegg, A., Jeff Waldock, Sonia Hendy-Isaac and Ruth Lawton. 2012. Pedagogy for employability. York, UK: Higher Education Academy.

Pollard, E., Wendy Hirsh, Matthew Williams, Jonathan Buzzeo, Rosa Marvell, Arianna Tassinari, Christine Bertram et al. 2015. Understanding Employers' Graduate Recruitment and Selection Practices: Main report. London: Department for Business, Innovation and Skills.

Pugatch, T. and Nicholas Wilson. 2018. "Nudging study habits: A field experiment on peer tutoring in higher education." Economics of Education Review 62: 151-161.

doi:10.1016/j.econedurev.2017.11.003

Rae, D. 2007. "Connecting enterprise and graduate employability: Challenges to the higher education culture and curriculum?" Education + Training, 49 (8/9): 605-619.

doi.org/10.1108/00400910710834049

Roberts, J. 2018. "Nudge-Proof: Distributive Justice and the Ethics of Nudging." Michigan Law Review, 116(6): 1045-1066.

Roulin, N. and Adrian Bangerter. 2013. 'Students' use of extra-curricular activities for positional advantage in competitive job markets." Journal of Education and Work 26 (1): 21 47. doi:10.1080/13639080.2011.623122 
Rowley, G. and Kate Purcell. 2001. 'Up to the Job? Graduates' Perceptions of the UK Higher Education Careers Service.” Higher Education Quarterly 55 (4): 416-435. doi:10.1111/1468$\underline{2273.00196}$

Saghai, Y. 2013. "Salvaging the concept of nudge." Journal of Medical Ethics, 39: 487-493.

Selinger, E. and Kyle Whyte. 2011. "Is There a Right Way to Nudge? The Practice and Ethics of Choice Architecture.” Sociology Compass 5 (10): 923-935. doi:10.1111/j.1751$\underline{9020.2011 .00413 . x}$

Smith, B.O., Dustin R. White, Patricia C. Kuzyk, and James E. Tierney. 2018. "Improved grade outcomes with an e-mailed "grade nudge""'. The Journal of Economic Education, 49 (1): 1-7. doi: $\underline{10.1080 / 00220485.2017 .1397570}$

Speight, S., Natasa Lackovic and Lucy Cooker. 2013. "The Contested Curriculum: Academic learning and employability in higher education." Tertiary Education and Management 19 (2): 112-126. doi: $10.1080 / 13583883.2012 .756058$

Stevenson, J. and Sue Clegg. 2011. "Possible selves: students orientating themselves towards the future through extracurricular activity." British Educational Research Journal 37 (2): 231-246. doi: $\underline{10.1080 / 01411920903540672}$

Sunstein, C. 2015. "Fifty Shades of Manipulation.” International Journal of Marketing Behaviour 213, 1-32: 10.2139/ssrn.2565892

Thaler, R.H. and Cass R. Sunstein. 2008. Nudge: Improving Decisions about Health, Wealth, and Happiness. New Haven: Yale University Press.

Thompson, L.J., Gordon Clark, Marion Walker, and J. Duncan Whyatt. 2013. “'It's just like an extra string to your bow': Exploring higher education students' perceptions and 
experiences of extracurricular activity and employability." Active Learning in Higher Education 14 (2): 135-147. doi:10.1177/1469787413481129

Tymon, A. 2013. “The student perspective on employability.” Studies in Higher Education 38 (6): 841-856. doi:10.1080/03075079.2011.604408

Watson, R. 2011. "A rationale for the development of an extracurricular employability award at a British university." Research in Post-Compulsory Education 16 (3): 371-384. doi: $\underline{10.1080 / 13596748.2011 .602248}$

Watts, A.G. 1997. Strategic Directions for Careers Services in Higher Education. Cambridge: Careers Research and Advisory Centre/Association of Graduate Careers Advisory Services.

Watts, A.G. 2006. Career development learning and employability. York: The Higher Education Academy.

Wells, P. 2010. “A Nudge One Way, A Nudge the Other: libertarian paternalism as political strategy.” People, Place \& Policy Online, 4(3): 111-118. doi: 10.3351/ppp.0004.0003.0004.

White, M.D. 2013. Manipulation of choice. New York: Palgrave McMillan.

Wilkinson, T.M. 2013. “Nudging and Manipulation”, Political Studies, 61 (2): 341-355.

Wilton, N. 2012. "The impact of work placements on skills development and career outcomes for business and management graduates." Studies in Higher Education 37 (5): 603-620. doi: $\underline{10.1080 / 03075079.2010 .532548}$

Yorke, M. and Peter Knight. 2006. Learning \& Employability Series One: Embedding employability into the curriculum. York, UK: The Higher Education Academy. 


\begin{tabular}{|c|c|c|c|c|}
\hline Year & Total no. & No. students & No. of students & 'Nudged' \\
& Business & 'nudged' to & responding to \\
& students (3- & change to & nudge & students as \\
& year route) & placement route & & of overall \\
& & & & \\
placement \\
students per \\
year
\end{tabular}

Table one: number of students nudged and responding to nudge 


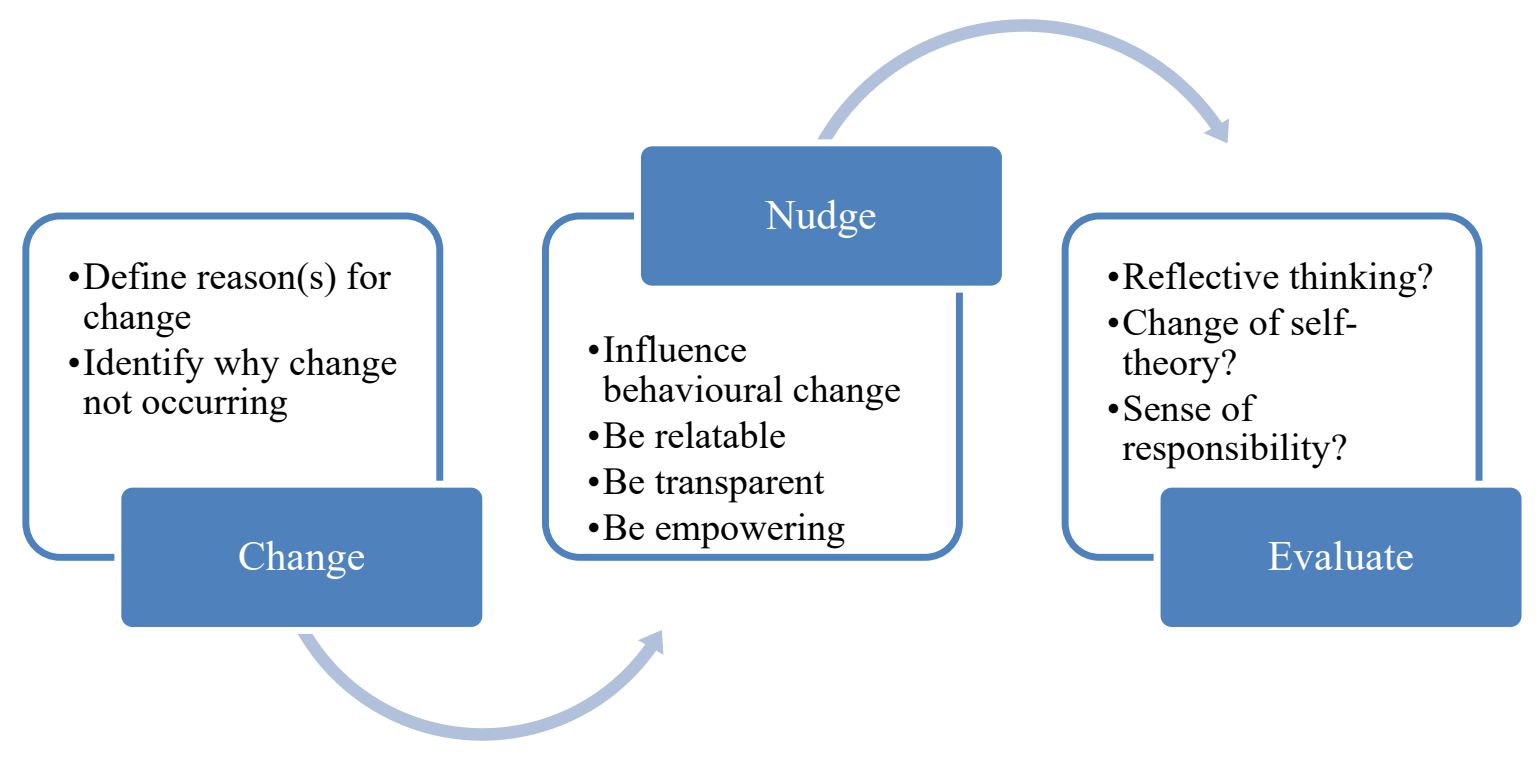

Figure one: influencing behavioural change in higher education students 